WellBeing International

WBI Studies Repository

$10-1998$

\title{
Assessment of side effects induced by injection of different adjuvant/antigen combinations in rabbits and mice
}

\author{
P.P.A.M. Leenaars \\ National Institute of Public Health and the Environment (RIVM) \\ M. A. Koedam \\ National Institute of Public Health and the Environment (RIVM) \\ P. W. Wester \\ National Institute of Public Health and the Environment (RIVM) \\ V. Baumans \\ Utrecht University \\ E. Claassen \\ Erasmus University of Rotterdam
}

See next page for additional authors

Follow this and additional works at: https://www.wellbeingintlstudiesrepository.org/bioamres

Part of the Animal Experimentation and Research Commons, Animal Studies Commons, and the Other Medical Sciences Commons

\section{Recommended Citation}

Leenaars, P. P. A. M., Rotterdam, Koedam, M. A., Wester, P. W., Baumans, V., Claassen, E., \& Hendriksen, C. F. M. (1998). Assessment of side effects induced by injection of different adjuvant/antigen combinations in rabbits and mice. Laboratory animals, 32(4), 387-406. DOI: https://doi.org/10.1258/

002367798780599884

This material is brought to you for free and open access by WellBeing International. It has been accepted for inclusion by an authorized administrator of the WBI Studies Repository. For more information, please contact wbisr-info@wellbeingintl.org.

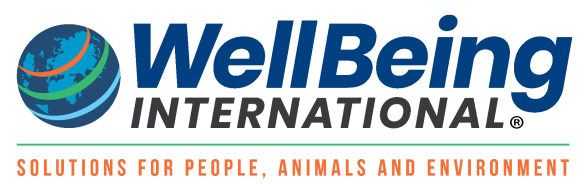




\section{Authors}

P.P.A.M. Leenaars, M. A. Koedam, P. W. Wester, V. Baumans, E. Claassen, and C. F.M. Hendriksen 


\title{
Assessment of side effects induced by injection of different adjuvant/antigen combinations in rabbits and mice
}

\author{
P. P. A. M. Leenaars ${ }^{1,2,3}$, M. A. Koedam ${ }^{1}$, P. W. Wester ${ }^{1}$, V. Baumans ${ }^{4}$, \\ E. Claassen ${ }^{3,5}$ \& C. F. M. Hendriksen ${ }^{1}$ \\ ${ }^{1}$ National Institute of Public Health and the Environment (RIVM), Bilthoven, ${ }^{2}$ Division Immunological \\ and Infectious Diseases, TNO Prevention and Health, Leiden, ${ }^{3}$ Department of Immunology, Erasmus \\ University Rotterdam, ${ }^{4}$ Department of Laboratory Animal Science, Utrecht University and ${ }^{5}$ Institute \\ for Animal Science and Health (ID-DLO), Lelystad, The Netherlands
}

\section{Summary}

We evaluated the side effects induced by injection of Freund's adjuvant (FA) and alternative adjuvants combined with different antigens. Rabbits and mice were injected subcutaneously, intramuscularly (rabbits) and intraperitoneally (mice) with different adjuvants (FA, Specol, RIBI, TiterMax, Montanide ISA50) in combination with several types of antigens (synthetic peptides, autoantigen, glycolipid, protein, mycoplasma or viruses). The effects of treatment on the animals' well-being were assessed by clinical and behavioural changes (POT and LABORAS assays) and gross and histopathological changes. In rabbits, treatment did not appear to induce acute or prolonged pain and distress. Mice showed behavioural changes immediately after (predominantly secondary) immunization. Injection of several adjuvant/ antigen mixtures resulted in severe pathological changes, depending on adjuvant, type of antigen, animal species used and route of injection. Both rabbits and mice showed pathological changes ranging from marked to severe after injection of FA, and ranging from minimal to marked after Specol and Montanide injections. Pathological changes after RIBI injections were severe in rabbits, though slight in mice. After TiterMax injections, pathological changes were moderate in rabbits, though severe in mice. In conclusion, injection of FA according to present guidelines resulted mostly in severe pathological changes, whereas only very few clinical and behavioural signs indicated prolonged severe pain. Our findings indicate that Montanide ISA50 and Specol induce acceptable antibody titres, and cause fewer pathological changes than FA. Thus they are effective alternatives to FA.

Keywords Adjuvants; immunization; pathology; distress; pain; refinement

Immunization procedures are frequently applied in laboratory animals, in many cases to produce specific polyclonal antibodies to different kinds of weakly immunogenic antigens. The immune response is enhanced

Correspondence to: Marlies Leenaars, RIVM, PO Box 1, 3720 $B A$ Bilthoven, The Netherlands. Fax: +31-30-2744408, E-mail: Marlies.Leenaarsorivm.nl by adding an adjuvant to the antigen. Freund's complete adjuvant (FCA) is commonly used for this purpose, because it evokes high-level and long-lasting humoral and cellular immunity to a wide range of antigens. However, on account of its severe side effects the use of FCA in laboratory animals is now discouraged (e.g. Canadian 
Council on Animal Care 1991, Veterinary Public Health Inspectorate 1993). Alternative adjuvants have been recommended to reduce pain in immunized animals /reviewed in Claassen \& Boersma 1992, Vogel \& Powell 1995, Cox \& Coulter 1997). An effective alternative to FCA would be an adjuvant that induces minimal side effects and acceptable antibody responses. It should also be easy to prepare, commercially available and inexpensive. Most adjuvant evaluation studies emphasize the immunological properties. Because the aim of finding an alternative to FCA is reducing pain and distress in laboratory animals, the side effects evoked by administration ought to be considered as well.

These side effects may be assessed on clinical, behavioural, biochemical, and histopathological grounds. Morton and Griffiths (1985) and Wallace et al. \{1990\} issued guidelines on the recognition of pain, distress and discomfort in experimental animals. Assessment includes general appearance, body weight, clinical signs, unprovoked behaviour, and responses to appropriate stimuli. Elevated levels of hormones or metabolites may serve as indicators of pain, though interpretation may be problematic (Broom \& Johnson 1993). Irwin (1968) developed the Primary Observation Test (POT) to assess pain after injection of pharmacological agents. Jansen van 't Land and Hendriksen (1995) described a system based on locomotor activity to evaluate discomfort. A recently developed behaviour registration system, LABORAS, (Van de Weerd 1996, Bulthuis et al. 1997) automatically records six different categories of behaviour (immobility, locomotion, climbing, grooming, eating, drinking) during prolonged periods of time.

LABORAS seems promising for extensive behavioural studies. Side effects of adjuvants can also be assessed on gross and histopathological changes.

Side effects occurring after administration of FCA are well-documented but studies evaluating side effects induced by alternative adjuvants are scarce (Johnston et al. 1991, Deeb et al. 1992). To obtain more information on side effects induced by FA and alternative adjuvants, we performed comparative studies in rabbits and mice. The studied alternative adjuvants (Specol, RIBI, TiterMax and Montanide ISA50) are commercially available and easy to prepare. Antibody responses and clinical, behavioural, and pathological changes were compared after injection of different combinations of adjuvant and antigen by different routes.

\section{Animals, materials and methods}

\section{Animals}

New Zealand White rabbits (Oryctolagus cuniculus) of both sexes were obtained from the specific-pathogen-free (SPF) breeding centre of the National Institute of Public Heath and the Environment (RIVM) in Bilthoven, The Netherlands. The rabbits were about 6 months old and weighed between 3.5 and $4.0 \mathrm{~kg}$ initially. They were individually housed in stainless steel or plastic cages, at environmental temperature 20 $21^{\circ} \mathrm{C}$, and under a $12 \mathrm{~h}$ day/night light cycle. The relative humidity ranged between 45 and $60 \%$. They were fed rabbit chow $180 \mathrm{~g} /$ day, Hope Farms BV, Woerden, The Netherlands), and tap water was available ad libitum.

BALB/c/Rivm mice of both sexes were bred SPF at the RIVM breeding facilities and were used at 10-14 weeks of age. They were housed in groups of five mice (one sex) under SPF conditions in Macrolon type II cages, at environmental temperature of $20-22^{\circ} \mathrm{C}$, relative humidity $50-70 \%$, and under a $12 \mathrm{~h}$ day/ night light cycle. They were fed a commercial diet (Hope Farms BV, Woerden, The Netherlands) and provided with tap water ad libitum. The behavioural experiment LABORAS was conducted at Utrecht University. Female BALB/cAnCrRyCpbRivU mice maintained at the Central Laboratory Animal Institute (GDL), Utrecht University, The Netherlands, were used at 10-12 weeks of age. These mice were housed individually in Macrolon type II cages, at environmental temperature $20-22^{\circ} \mathrm{C}$, relative humidity $50-70 \%$, and under a reversed $12 \mathrm{~h}$ day/night light cycle.

\section{Adiuvants}

Freund's complete adjuvant (FCA; Difco Laboratories, Detroit, $\mathrm{MI}$ ) consists of $85 \%$ 
paraffin oil (mineral oil; Bayol F) and 15\% emulsifier (mannide monooleate) with added heat-killed Mycobacterium butyricum $(0.5 \mathrm{mg} / \mathrm{ml})$. Freund's incomplete adjuvant (FIA; Difco Laboratories, Detroit, MI) contains the same ingredients as FCA, except for mycobacteria. The term FA is used in this paper to indicate that FCA was used in primary and FIA in secondary injection. Specol (ID-DLO, Lelystad, The Netherlands; Bokhout et al. 1981, Boersma et al. 1992) is $90 \%$ mineral oil (Marcol 52) and 10\% emulsifier (Span 85 and Tween 85). RIBI (Sanbio BV, Uden, The Netherlands; Rudbach et al. 1995| consists of metabolizable oil |squalene; $2 \%$ in final volume of adjuvant/antigen|, emulsifier (Tween 80) and microbial components: $0.5 \mathrm{mg} / \mathrm{ml}$ monophosphoryl lipid A (MPL), $0.5 \mathrm{mg} / \mathrm{ml}$ synthetic trehalose dicorynomycolate (TDM) and (when used in rabbits) $0.5 \mathrm{mg} / \mathrm{ml}$ cell wall skeleton (CWS). TiterMax (CytRx, Norcross, GA; Hunter et al. 1995) consists of a metabolizable oil (squalene), emulsifier (sorbitan monooleate 80), a patented block copolymer CRL-8941 and microparticulate silica coated with CRL8941). Montanide ISA50 (Seppic, Paris, France; Ganne et al. 1994) consists of $85 \%$ mineral oil and $15 \%$ emulsifier (mannide oleatel. Mixing FCA, FIA, Specol, Montanide or TiterMax with aqueous antigen solution produces water-in-oil emulsions. Mixing RIBI with aqueous antigen solution produces an oil-in-water emulsion.

\section{Antigens}

Synthetic peptide (SPek15a, 27 amino acids, containing a B and T cell epitope) was synthesized as described by Zegers et al. (1993). Synthetic peptide $($ SP215, 21 amino acids, a homologue to the hinge region of the human IgG2 molecule) was synthesized as described by Boersma et al. (1989). Myelin basic protein (MBP; Sigma, St Louis, MO) is an autoantigen derived from the bovine brain, and consists of 173 amino acids, $18.5 \mathrm{kDa}$ (Van Noort et al. 1993). Galactocerebroside (MBL-TNO, Rijswijk, The Netherlands; Gerritse et al. 1993| is a glycolipid. Bovine serum albumin (BSA) was obtained from Sigma, St Louis, MO (A-9647). Measles virus (Edmonston strain;
$10^{7} \mathrm{CCID}_{50} / \mathrm{ml}$ Van Binnendijk et al. 1994), rubella virus (HPV-77 strain; $10^{7} \mathrm{CCID}_{50} / \mathrm{ml}$; Parkman et al. 1966) and mumps virus (Enderson strain; $10^{7} \mathrm{CCID}_{50} / \mathrm{ml}$ ) were kindly supplied by Dr N Elzinga (RIVM, Bilthoven, The Netherlands). HIV peptides conjugated to tetanus toxoid were prepared by Dr P. de Vries (RIVM, Bilthoven, The Netherlands). Mycoplasma pneumoniae (MAC strain; Su et al. 1990) is a particulate antigen $(0.1-0.8 \mu \mathrm{m})$ which was kindly supplied by Dr A Angulo (RIVM, Bilthoven, The Netherlands). The antigens (amounts per rabbit in Table 1 and per mouse in Table 2) were diluted in sterile phosphate-buffered saline (PBS), except for galactocerebroside which was diluted in dimethyl sulphoxide (DMSO).

\section{Adjuvant/antigen preparation}

Adjuvant/antigen and adjuvant/PBS mixtures were prepared according to the manufacturer's instructions. Freund's adjuvant emulsions were prepared by mixing FA and aqueous antigen solution $(1: 1)$, using two glass syringes with Luer Lock connector. The antigen was added to FA via the connector and mixed for one minute. Specol emulsions were prepared by adding the aqueous antigen solution (Specol : antigen $=5: 4$ ) dropwise to Specol while vortexing. RIBI emulsions were prepared by warming the RIBI vial to $40-45^{\circ} \mathrm{C}$ for $5 \mathrm{~min}$, reconstituting a final volume of $2 \mathrm{ml}$ with the aqueous antigen solution in the RIBI vial and vortexing for $3 \mathrm{~min}$. TiterMax was emulsified with aqueous antigen solution (1:1) similarly to FA, except that the aqueous antigen solution was added in two steps. Montanide ISA50 emulsions were prepared by pouring Montanide ISA50 in a glass tube, adding the aqueous antigen solution with a syringe and making 10 up and down strokes.

\section{Experimental design}

Studies were performed in rabbits and mice. Adjuvant/antigen combinations inducing obvious problems were not unnecessarily repeated. The experimental designs for the studies in rabbits are outlined in Table 1 and for the studies in mice in Table 2. In rabbits, 
Table 1 Experimental design for immunization studies in rabbits

\begin{tabular}{|c|c|c|c|c|c|}
\hline & & Exp. $1^{a}$ & Exp. II & Exp. III & Exp. IV \\
\hline \multirow[t]{6}{*}{ Adjuvant } & FA & + & + & + & + \\
\hline & Specol & + & + & + & + \\
\hline & RIBI & + & - & - & - \\
\hline & TiterMax & + & - & - & - \\
\hline & Montanide $15 A 50$ & - & + & - & + \\
\hline & No adjuvant & + & + & - & + \\
\hline \multirow{9}{*}{$\begin{array}{l}\text { Antigen }{ }^{b} \\
\text { ( } \mu \text { g per injection) }\end{array}$} & SPek15a (200) & + & - & - & - \\
\hline & Galacto $(200)$ & + & - & - & - \\
\hline & M. pneu. (87) & + & - & - & - \\
\hline & Rubella $^{c}$ & - & + & - & - \\
\hline & BSA (1000) & - & + & - & - \\
\hline & Measles ${ }^{c}$ & - & - & + & - \\
\hline & Mumps ${ }^{c}$ & - & - & + & - \\
\hline & HIV-pept/tt I & - & - & - & + \\
\hline & HIV-pept/tt II & - & - & - & + \\
\hline \multirow[t]{2}{*}{ Route } & S.C., volume in $\mathrm{ml}$ & $0.5^{\mathrm{d}}$ & 0.1 & $4 \times 0.25$ & $4 \times 0.1$ \\
\hline & I.m., volume in $\mathrm{ml}$ & $0.5^{\mathrm{d}}$ & 0.1 & - & - \\
\hline \multirow[t]{2}{*}{ Immunization schedule } & Injection, day & 0,28 & 0,28 & 0,35 & $0,28,84$ \\
\hline & Dissection, day & 42 & 42 & 49 & 92 \\
\hline \multirow{3}{*}{$\begin{array}{l}\text { Additional parameters to } \\
\text { assess side effects }\end{array}$} & Body weight & + & + & - & - \\
\hline & Body temperature & + & - & - & - \\
\hline & Locomotor activity & + & - & - & - \\
\hline $\begin{array}{l}\text { Number of animals injected } \\
\text { per route and per adjuvant' } \\
\text { antigen combination }\end{array}$ & & 2 & 2 & 5 & 1 \\
\hline
\end{tabular}

also described in Leenaars et al. (1994)

bPek15a = synthetic peptide; Galacto = galactocerebroside; $M$. pneu. = Mycoplasma pneumoniae; BSA = bovine serum albumin; HIV/pept/tt $=$ HIV peptides conjugated to tetanus toxoid

'Amount of antigen described in Antigen section of 'Animals, materials and methods'

${ }^{\mathrm{d}} \mathrm{RIBI}$ emulsions: $2 \times 0.5 \mathrm{ml}$; TiterMax emulsions: $0.08 \mathrm{ml}$ (as recommended by the manufacturers)

four experiments were performed, injecting animals subcutaneously (s.c.) on the flank or intramuscularly (i.m.) in the posterior thigh. In order to be able to discriminate between primary and secondary inoculations, single adjuvant/antigen injections were given at separate sites, except in rabbit experiments III and IV. These experiments were combined with routine polyclonal antibody production, involving four injections (s.c.) at one time point, on account of low concentration of antigen. In mice, three experiments were performed. The animals were injected intraperitoneally (i.p.) or s.c. in the neck (primary injection) and s.c. in the groin (secondary injection). Control rabbits and mice received antigen only. At selected time points blood samples were taken to determine antibody production, except for mice experiment III (see Table 2), which was a behavioural study only. Clinical and behavioural abnormalities occurring during the experiments, and pathological changes at the end of each experiment were studied as described below.

\section{Clinical and behavioural parameters}

General condition (appearance and clinical abnormalities) of the rabbits and mice was observed daily as described by Morton and Griffiths (1985). Abdomen of i.p. injected mice and s.c./i.m. injection sites were pal- 
Table 2 Experimental design for immunization studies in mice

\begin{tabular}{|c|c|c|c|c|c|c|}
\hline & & Exp. $1^{a}$ & Exp. $1^{a}$ & Exp. $1^{a}$ & Exp. II & Exp. III \\
\hline \multirow[t]{6}{*}{ Adjuvant } & FA & + & + & + & + & + \\
\hline & Specol & + & + & + & + & - \\
\hline & RIBI & - & - & - & + & - \\
\hline & TiterMax & - & - & - & + & - \\
\hline & Montanide ISA50 & - & - & - & + & - \\
\hline & No adjuvant & + & + & + & + & + \\
\hline Antigen ${ }^{b}$ & MBP (100) & + & - & - & - & - \\
\hline \multirow[t]{3}{*}{ ( $\mu \mathrm{g}$ per injection) } & M. pneu. (15) & - & + & - & - & - \\
\hline & SP215 (50) & - & - & + & + & - \\
\hline & No antigen & - & - & - & + & + \\
\hline \multirow[t]{2}{*}{ Route } & S.c., volume in $\mathrm{ml}$ & 0.2 & 0.1 & 0.1 & $0.1^{\mathrm{c}}$ & - \\
\hline & l.p., volume in $\mathrm{ml}$ & 0.2 & 0.2 & 0.1 & 0.2 & 0.2 \\
\hline \multirow[t]{2}{*}{ Immunization schedule } & Injection, day & 0,42 & 0,42 & 0,42 & 0,42 & 0 \\
\hline & Dissection, day & 49 & 47 & 47 & 47 & 18 \\
\hline \multirow{3}{*}{$\begin{array}{l}\text { Additional parameters to } \\
\text { assess side effects }\end{array}$} & Body weight & + & + & + & - & - \\
\hline & POT $^{d}$ & + & + & + & - & - \\
\hline & LABORAS & - & - & - & - & + \\
\hline $\begin{array}{l}\text { Number of animals injected per } \\
\text { route and per adjuvant/antigen } \\
\text { combination }\end{array}$ & & 5 & 5 & 5 & 5 & 4 \\
\hline
\end{tabular}

apartly described in Leenaars et al. (1995)

${ }^{\mathrm{b}} \mathrm{MBP}=$ myelin basic protein (autoantigen); $M$. pneu. = Mycoplasma pneumoniae; $\mathrm{SP215}=$ synthetic peptide

TiterMax emulsions: $0.05 \mathrm{ml}$ (as recommended by the manufacturer)

Primary Observation Test

eLaboratory Animal Behaviour Observation Registration and Analysis System

pated to monitor signs of pain. Injection sites were examined for swelling the day after injection and weekly thereafter. Additional clinical or behavioural parameters were studied to evaluate side effects (see Tables 1 and 2). These parameters are described below.

\section{Body weight, body temperature, locomotion activity}

Rabbits were weighed (experiments I and II) weekly. Mice (experiment I) were weighed before injection, 3 days after injection and twice-weekly thereafter. Body temperature of rabbits (experiment I) was measured twice a week in a restraining box; after $30 \mathrm{~min}$ acclimatization, the rectal temperature was recorded four times in $30 \mathrm{~min}$. The mean of these four temperatures was taken as the body temperature. Locomotor activity of rabbits was studied during one week following primary and secondary injection, obser- ving the animals moving freely in the animal room.

\section{Primary Observation Test}

Behavioural changes and physiological state of the mice were studied (mice experiment I) using the POT. POT is a systematic quantitative procedure described by Irwin (1968) and modified by Professor Dr B Olivier (Solvay Duphar, Weesp, The Netherlands). It involves an initial phase of undisturbed observation followed by a manipulative phase during which the animal is subjected to different stimuli. It was performed before injection, 3 days thereafter and then weekly. Per group $(n=5)$, mice were placed in an observation chamber. After an adaptation period of one hour the animals' undisturbed behaviour, i.e. dispersion in the cage, apathy, startle-reaction, restlessness, watchfulness and respiration, was observed. Then the ani- 
mals were individually transferred onto the viewing arena and arousal response to transfer, spatial locomotion, gait, slip resistance, righting reflex, exophthalmos and piloerection, were observed. Then, touch-reflex, provoked-freezing, provoked biting, skin colour, body tone, pupil size, urination-defecation and vocalization, were studied throughout individual handling. After handling, they were placed in the observation chamber again to study grooming. Behavioural changes and physiological state were scored per mouse.

\section{Behaviour registration system $L A B O R A S$}

A newly developed behaviour registration system LABORAS (Van de Weerd 1996, Bulthuis et al. 1997) was used to register behavioural patterns of individually-housed mice (mice, experiment III). LABORAS is a fully automated device capable of deducing these behavioural categories: locomotion, immobility, climbing, grooming, eating, drinking. The animal is placed in a Macrolon type II cage located on a sensing platform. The mechanical vibrations caused by the animals' movements are transduced into electrical signals and recorded. The signals are translated into the six separate behavioural categories by computer. On day $0,15 \mathrm{~min}$ before the start of the dark period $\langle=15 \mathrm{~min}$ before start of recording period), mice were injected with FCA or PBS $(0.2 \mathrm{ml}$ i.p.) and placed in the cage on the sensing platform. Movements were recorded during the first $4 \mathrm{~h}$ of the dark period every other day during 16 days. Per day (i.e. first $4 \mathrm{~h}$ of dark period) the relative time spent on each behavioural category was calculated and analysed. After a square-root transformation, data were statistically analysed using a $t$-test to establish significant behavioural differences between FCA and PBS injected mice. The level of statistical significance was set at $P<0.05$.

\section{Pathology}

At the end of each experiment, rabbits were anaesthetized by intravenous injection of $2.5 \mathrm{ml}$ sodium pentobarbital $(60 \mathrm{mg} / \mathrm{ml})$ before bleeding via cardiac puncture. Mice were anaesthetized before orbital bleeding by i.m. injection of $0.1 \mathrm{ml}$ of a mixture of keta- mine $(50 \mathrm{mg} / \mathrm{ml})$, xylazine $(20 \mathrm{mg} / \mathrm{ml})$ and atropine $(1 \mathrm{mg} / \mathrm{ml})$ in a 7:3:1 volume ratio. Necropsy in rabbits and mice included dissection and examination of injection sites and at least abdominal organs. For histopathological evaluation, tissue of injection. sites, a sample of the omentum of all i.p. injected mice, and tissue of organs showing macroscopic abnormalities, were fixed in $4 \%$ neutral buffered formaldehyde, embedded in paraffin, sectioned at $5 \mu \mathrm{m}$, and stained with haematoxylin and eosin. Gross lesions were documented during necropsy and microscopy was performed in selected representative samples. In rabbits and in s.c. injected mice the primary and secondary injection sites were scored separately. The scoring was based on the size and character of the lesions found. In individual rabbits the severity of lesions was scored according to Table 3. Microscopy was used to verify macroscopical observations (Figs 1A-B). In individual mice, the severity of s.c. lesions was scored (macroscopically and microscopically) according to Table 4 . In order to be able to grade pathological lesions, taking into account the supposed discomfort, the categories shown in Tables 3 and 4 served as a general guideline for classification. In i.p. injected mice, the severity of abdominal lesions was mainly assessed macroscopically, based on the presence of abdominal effusions, adhesions, intestinal dilatation, presence of 'plaques' and omentum retrahens. Microscopical determination of severity of peritonitis was used to verify macroscopical observations. Examples of microscopic severity grade of lesions in mice are given in Figs $1 \mathrm{C}-\mathrm{F}$ (s.c.) and Fig $1 G$ (i.p.).

\section{Antibody responses}

Blood samples were taken to determine antibody production (except mice experiment III). As this paper focuses on the side effects induced by adjuvants, antibody production results will be summarized. More detailed information on antibody titres of rabbit experiment I can be obtained from Leenaars et al. (1994) and of mice experiment I and II from Leenaars et al. (1995) and Leenaars et al. (in press), respectively. Antibody production 
Table 3 Pathological findings at injection sites of rabbits subcutaneously or intramuscularly injected with different adjuvant/antigen combinations; applied classification and grading ${ }^{a}$

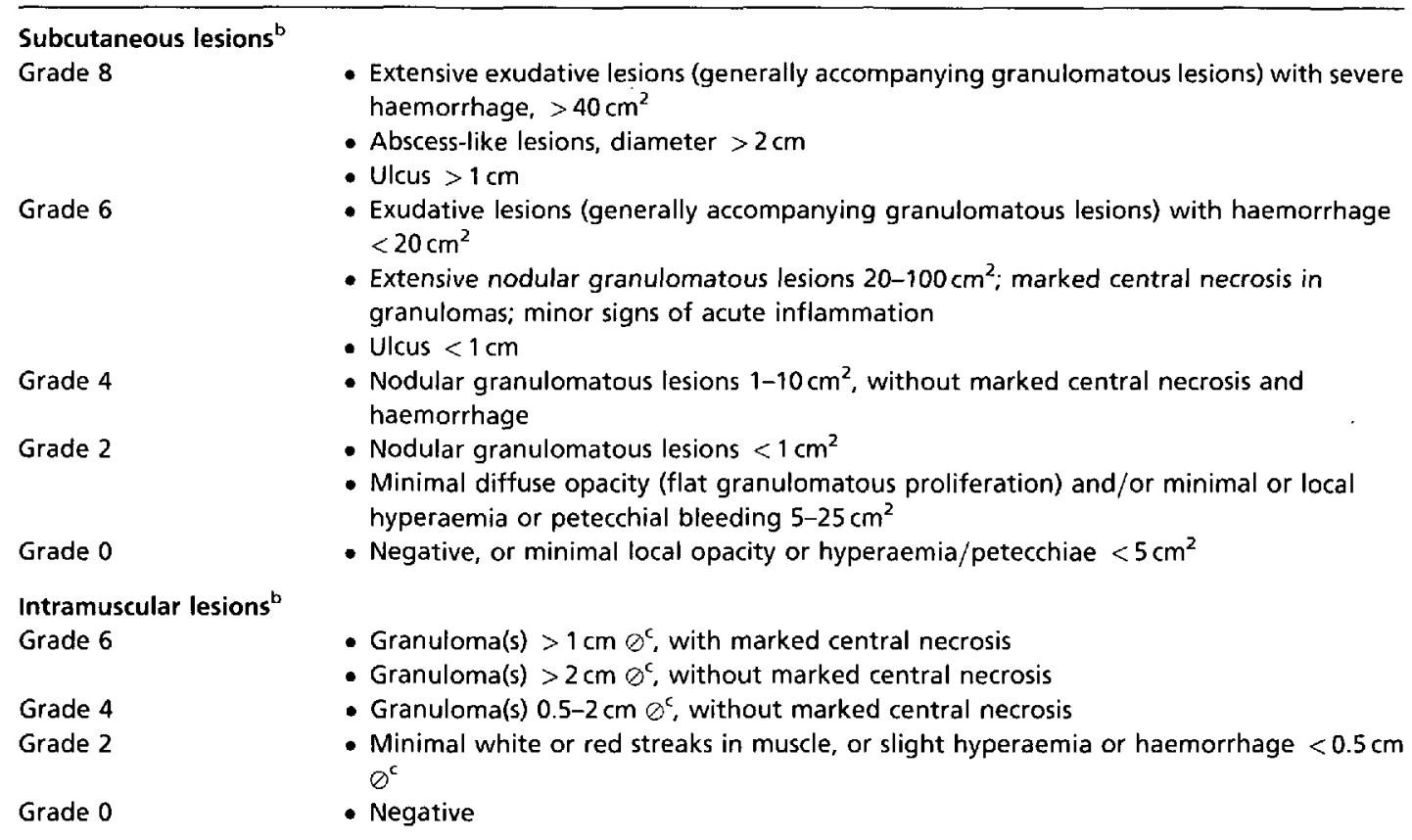

an some cases lesions were given an in-between score

When different lesions were present, the highest score was used to classify the injection site

'Transverse diameter, perpendicular to muscle fibres

Table 4 Pathological findings at injection sites of mice subcutaneously injected with different adjuvant/ antigen combinations; applied classification and grading ${ }^{a}$

\begin{tabular}{|c|c|c|c|c|}
\hline \multirow[b]{2}{*}{ Grade $^{\mathrm{b}}$} & \multicolumn{2}{|l|}{ Primary } & \multicolumn{2}{|l|}{ Secondary } \\
\hline & Macroscopy & Microscopy & Macroscopy & Microscopy \\
\hline 3 & - S.C. nodule $>4 \mathrm{~mm}$ & $\begin{array}{l}\text { - Marked to severe } \\
\text { fibrosis, diffuse inflam- } \\
\text { mation and cellularity; } \\
\text { (epi)dermal abnormal- } \\
\text { ities }^{c}\end{array}$ & $\begin{array}{l}\text { Nodule externally } \\
\text { visible; s.c. nodule } \\
>5 \mathrm{~mm} \text { or large } \\
\text { amount of white tissue } \\
\text { around thigh muscles }\end{array}$ & $\begin{array}{l}\text { - Severe diffuse inflam- } \\
\text { mation with marked } \\
\text { cellularity (and gener- } \\
\text { ally necrotizing granu- } \\
\text { loma) }\end{array}$ \\
\hline 2 & - S.c. nodule $2-4 \mathrm{~mm}$ & $\begin{array}{l}\text { Marked fibrosis and } \\
\text { slight to moderate } \\
\text { diffuse inflammation, } \\
\text { cellularity and } \\
\text { granuloma formation }\end{array}$ & $\begin{array}{l}\text { Bulging white mass } \\
\text { externally visible; s.c. } \\
\text { marked amount of } \\
\text { white tissue }\end{array}$ & $\begin{array}{l}\text { Marked diffuse inflam- } \\
\text { mation with moderate } \\
\text { cellularity (and } \\
\text { generally necrotizing } \\
\text { granuloma) }\end{array}$ \\
\hline 1 & - S.c. nodule 1-2 mm & $\begin{array}{l}\text { - Slight to moderate } \\
\text { fibrosis, diffuse inflam- } \\
\text { mation, cellularity and } \\
\text { granuloma formation }\end{array}$ & $\begin{array}{l}\text { White mass externally } \\
\text { visible, no swelling; s.c. } \\
\text { slight to moderate } \\
\text { amount of white tissue }\end{array}$ & $\begin{array}{l}\text { Moderate diffuse } \\
\text { inflammation }\end{array}$ \\
\hline 0.5 & $\begin{array}{l}\text { - S.c. nodule }<1 \mathrm{~mm} \\
\text { - S.c. negative; hairless } \\
\text { area }<2 \mathrm{~mm}\end{array}$ & $\begin{array}{l}\text { - Minimal fibrosis, diffuse } \\
\text { inflammation, cellular- } \\
\text { ity and granuloma } \\
\text { formation }\end{array}$ & $\begin{array}{l}\text { Negative externally; s.c. } \\
\text { minimal amount of } \\
\text { white tissue }\end{array}$ & $\begin{array}{l}\text { - Minimal to slight } \\
\text { diffuse inflammation }\end{array}$ \\
\hline
\end{tabular}

an some cases in-between scores were given

bThe macroscopic and microscopic severity grades of a lesion are not necessarily similar

'Exudative nature usually dominates granuloma formation 

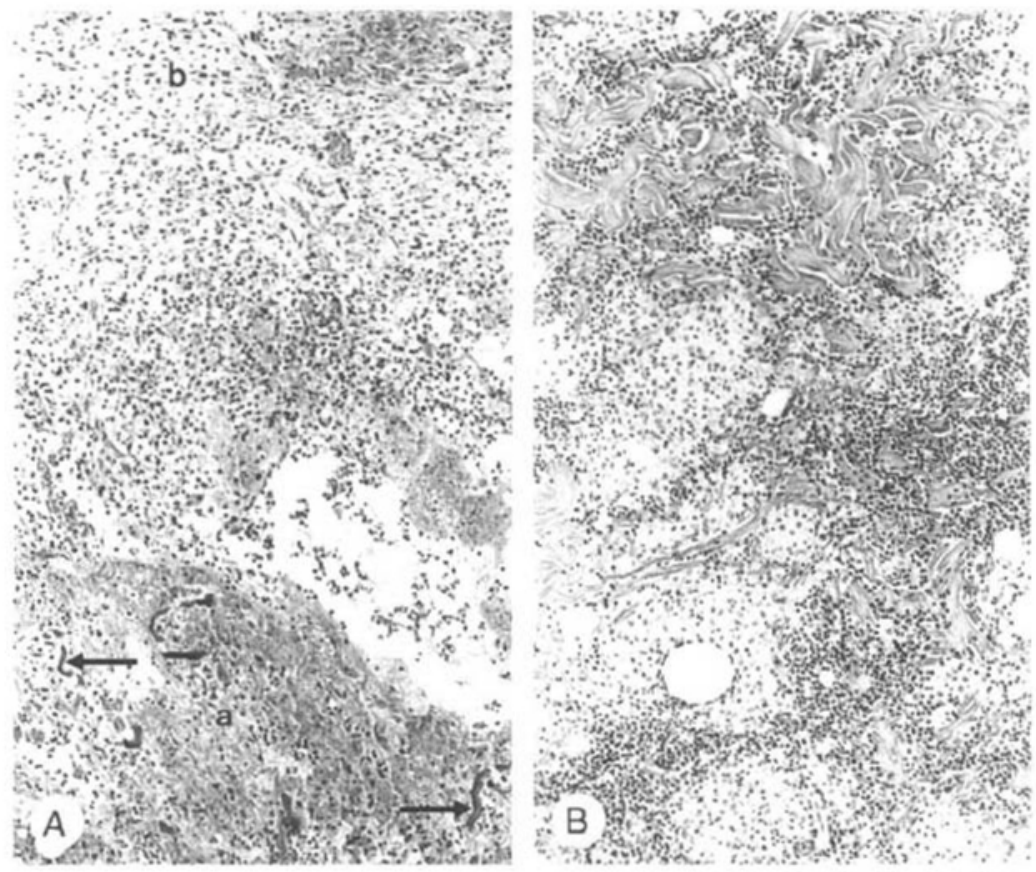

Fig 1 A Rabbit experiment III, s.c. FIA/measles virus, 2 weeks after secondary injection, score 8. Microscopical detail of palpable, extensive haemorrhagic lesions, total surface $300 \mathrm{~cm}^{2}$. a: Necrosis of pre-existent tissue, as shown by pre-existent collagen fibres (arrows), between cellular debris and fibrin. b: Fibroangioblastic proliferation with hyperaemia and haemorrhage. Considered primarily exudative, no granulomatous component present (HE $\times 110)$

Fig 1B Rabbit experiment II, s.c. Montanide ISA50/BSA, 2 weeks after secondary injection, score 4. Microscopical detail of a palpable lesion, grossly described as faint pink tissue with central hyperaemia and slight haemorrhage, measuring $12 \mathrm{~cm}^{2}$ and maximum width $0.5 \mathrm{~cm}$. Epithelioid granulomas, partly around oil spaces, and lympho-plasmacellular infiltrate between subcutaneous collagen fibres. Necrosis absent $(\mathrm{HE} \times 110)$

after adjuvant/antigen injection was correlated to antibody production after FA/antigen injection. Antibody titre after FA/antigen injection was set on $100 \%$ and antibody titres after other adjuvant/antigen injections were expressed relative to the titre after FA/antigen.

\section{Results}

\section{Clinical and behavioural signs}

Rabbits

Both after s.c. and i.m. injection, body weight and body temperature did not significantly differ between the control (antigen injected) and experimental (adjuvant/antigen injected) groups. Clinical abnormalities were observed in one rabbit, i.m. injected with RIBI/M. pneumoniae, showing discomfort during locomotor activity the first 4 days after primary injection.

Experiments $I+I I$ Subcutaneous injection sites in rabbits showed tissue swelling (see Table 5). Primary injection sites showed swelling mainly after FCA injection. At secondary injection sites, other adjuvants also caused swelling. FA and RIBI injection most frequently resulted in swelling. Swellings increased during 3-4 weeks after primary injection, and then decreased. Swellings after secondary immunization increased during the first week post injection. Intramuscular injected rabbits showed swellings only at Specol/BSA secondary injection sites. Palpation of s.c. and i.m. injection sites, produced no signs indicating pain. 

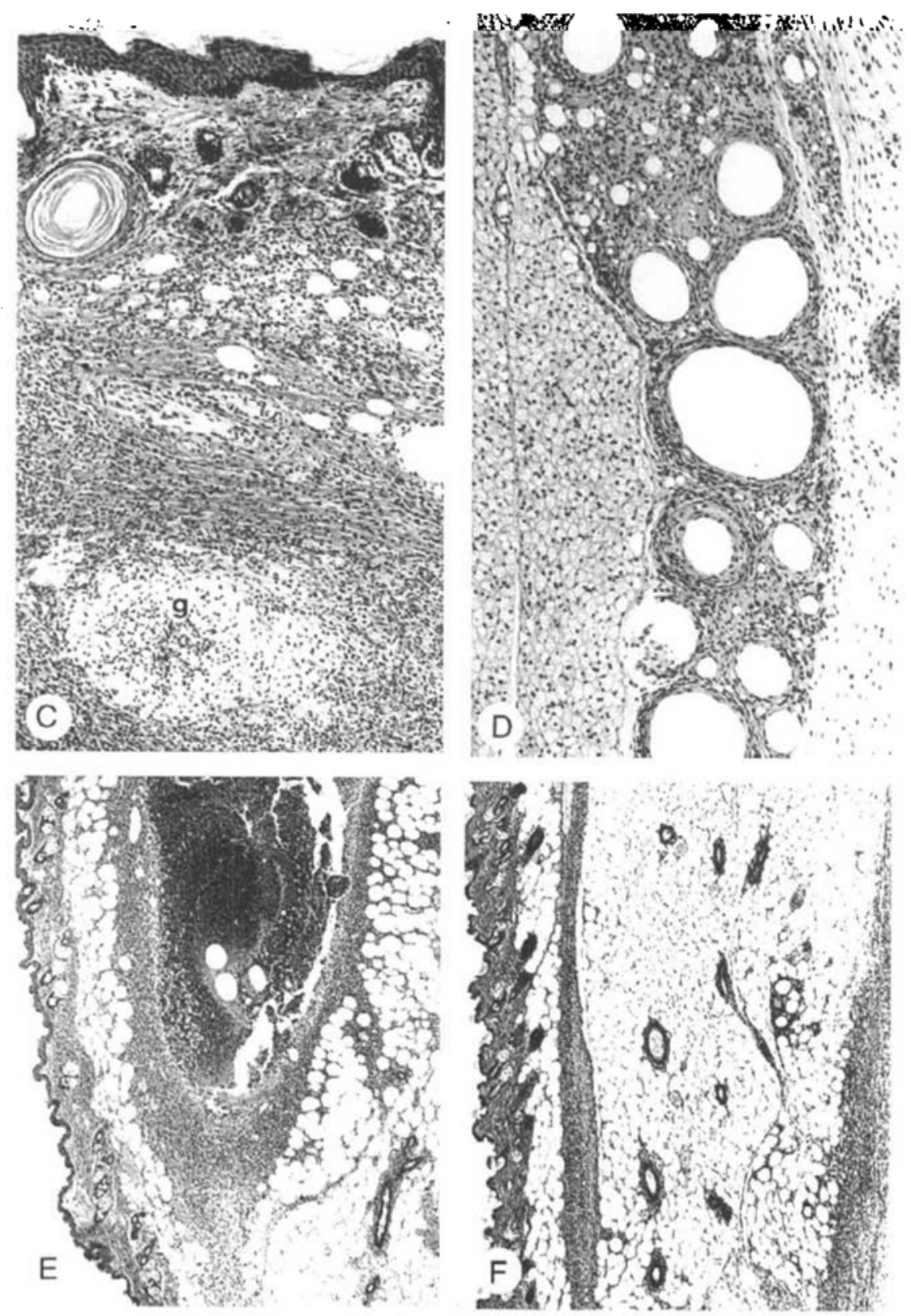

Fig 1C Mouse experiment II, s.c. TiterMax/SP215, 7 weeks after primary injection. Grossly hairless area, s.C. pale-yellow nodule $5 \mathrm{~mm}$ with slight haemorrhage, score 3. Microscopical detail shows acanthosis, severe fibrosis and diffuse inflammation, with marked cellularity and an occasional small granuloma (g) with central necrosis, score 3 (HE $\times 110)$

Fig 1D Mouse experiment II, s.c. Specol/SP215, 7 weeks after primary injection. Grossly white nodules $<2 \mathrm{~mm}$ and slight petechial bleeding in interscapular brown fat, score 1. Microscopically slight granuloma formation around oil spaces, moderate diffuse inflammation (not observable in this detail) and moderate fibrosis, score 1 $(\mathrm{HE} \times 110)$

Fig 1E Mouse experiment II, S.C. TiterMax/SP215, 5 days after secondary injection. Grossly prominent nodule, white viscous material inside thin capsule in s.c. fat, score 3. Microscopically fairly circumscribed lesion, essentially composed of large amount of cellular debris within reactive capsule, score 2.5 (HE $\times 44$ )

Fig 1 Fouse experiment II, s.c. RIBI/no antigen (PBS), 5 days after secondary injection. Grossly minimal amount of white tissue s.c. in the groin, not externally visible, score 0.5 . Microscopically moderate diffuse inflammation, score $1(\mathrm{HE} \times 44)$ 


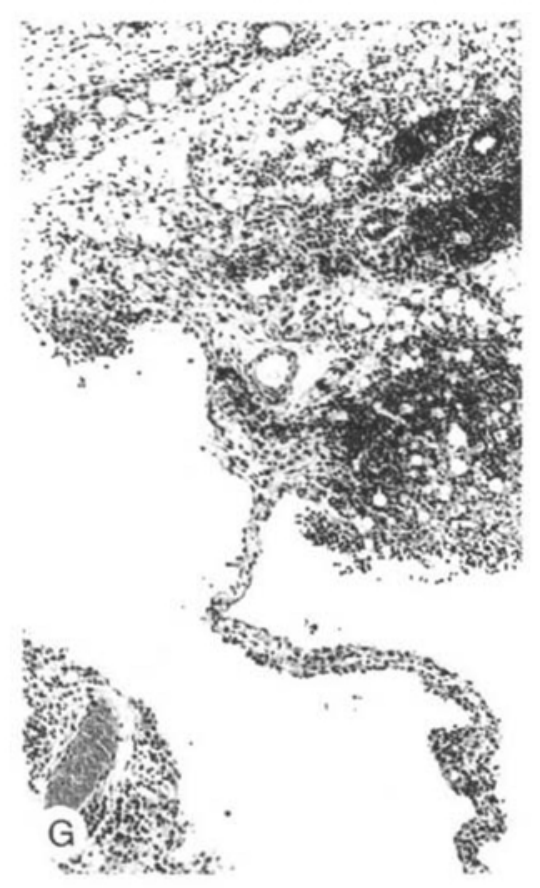

Fig 1G Mouse experiment II, i.p. Montanide ISA50/SP215, 5 days after secondary injection (omentum). Grossly slight consolidation of omental edge, score 0.5 (see Table 7). Microscopically in contrast granulomatous inflammation, mesothelium prominent or absent, score 3 . Also unaffected omentum present (not shown) (HE $\times 110)$

Experiments $I I I+I V \quad$ Swelling was observed at most injection sites of rabbits given measles or mumps antigen combined with FA or Specol, especially after secondary injection $\left(5-20 \mathrm{~cm}^{2}\right)$. When mumps antigen was combined with Specol, swellings were less extensive than when it was combined with FA. Injection of HIV-peptide conjugates combined with FA resulted in severe swelling, persistent till the end of the experiment. Injection of HIV-peptide conjugates combined with Specol resulted in swelling immediately after injection and slightly palpable swelling 4 weeks later. Rabbits injected with Montanide/HIV-peptide conjugates showed only slight swelling.

\section{Mice}

Experiment I Body weights decreased the first few days after primary injection of FCA/ antigen (five out of six groups; 5/6) and Specol/antigen (4/6), and reverted to normal within one week. Some clinical abnormalities were observed the first few days after adjuvant/antigen injection. Piloerection occurred the first 2 days after i.p. primary and secondary injection with FA/SP215 or FA/ MBP emulsions. After secondary injection, piloerection occurred in all groups, i.p. or s.c. given $M$. pneumoniae combined with an adjuvant. At s.c. injection sites of FCA/SP215 or FCA/MBP nodules (1-4 mm) were palpable, as in cases when mice were given s.c. M. pneumoniae with FA or Specol. The FCAinduced nodules were present from one week after injection till the end of the experiment. Specol nodules had disappeared 4 weeks after injection. Palpation of injection sites did not reveal signs of pain. In experiment I, secondary i.p injection caused the death of the mice when they were given FIA/SP215 (five

Table 5 Tissue swelling after subcutaneous injection of adjuvant/antigen mixtures in rabbits

\begin{tabular}{|c|c|c|c|c|c|c|c|c|c|c|c|}
\hline \multirow[b]{3}{*}{ Exp. } & \multirow[b]{3}{*}{ Antigen $^{a}$} & \multicolumn{10}{|c|}{ Adjuvant $^{\mathrm{b}}$} \\
\hline & & \multicolumn{2}{|l|}{ FA } & \multicolumn{2}{|c|}{ Specol } & \multicolumn{2}{|l|}{ RIBI } & \multicolumn{2}{|c|}{ TiterMax } & \multicolumn{2}{|c|}{ Montanide ISA50 } \\
\hline & & Prim $^{c}$ & $\operatorname{Sec}^{c}$ & Prim & $\mathrm{Sec}$ & Prim & $\mathrm{Sec}$ & Prim & $\mathrm{Sec}$ & Prim & $\mathrm{Sec}$ \\
\hline I & SPek15a & $-^{d}$ & - & - & - & - & - & - & - & & \\
\hline I & Galacto & - & ++ & - & - & - & ++ & - & - & & \\
\hline 1 & M. pneu. & - & ++ & - & + & - & ++ & - & + & & \\
\hline ॥ & Rubella & ++ & + & - & - & \multicolumn{2}{|c|}{ n.d. } & \multicolumn{2}{|c|}{ n.d. } & - & - \\
\hline II & BSA & ++ & + & - & ++ & \multicolumn{2}{|c|}{ n.d. } & \multicolumn{2}{|c|}{ n.d. } & + & ++ \\
\hline
\end{tabular}

${ }^{a}$ Antigens described under Table 1

${ }^{b}$ Antigen control (PBS + antigen injection): no abnormalities

'Maximum swelling at primary (prim) or secondary (sec) injection site

${ }^{-}{ }_{-}=$no abnormalities; $+=$swelling $<2 \mathrm{~cm} ;++$ swelling $>2 \mathrm{~cm}$; $\mathrm{n}$.d. $=$ not done 
out of five). It should be noted that the antigen, and not the adjuvant was responsible for these deaths. Most probably animals died as a result of anaphylactic shock as suggested by time course and observed circulatory disturbances.

Experiment II Piloerection and hunched posture was observed the first day after priming i.p. with FCA or TiterMax emulsions, and also after secondary immunization with FIA, TiterMax, Specol or Montanide emulsions. Mice still showed piloerection five days after secondary injection with FIA, TiterMax or Specol. After primary s.c. injection nodules were palpable in mice injected with FCA/SP215 (4-8 mm) or TiterMax $(5 \mathrm{~mm})$. Two mice died after secondary i.p. immunization with FIA/SP215 (2/5). Palpation of the abdomen of i.p. injected mice or nodules at the s.c. injection sites did not reveal signs of pain.

Using the POT procedure, apart from piloerection we did not observe changes in behaviour and physiological state. Assuming that lesions induced by i.p. FCA/antigen injection are painful, we compared activity at 3 weeks after i.p. injection of FCA/SP215 or PBS/SP215. There were no differences between these two groups (data not shown), indicating that at the time locomotor activity was minimally disturbed by FCA/SP215 injection.

\section{Behaviour registration system $L A B O R A S$}

In mice of experiment III, no clinical abnormalities were observed. The LABORAS system yielded significant differences in behavioural patterns between FCA and PBS injected animals. On the day of injection, locomotion, climbing, grooming, eating and drinking were significantly $(P<0.01)$ decreased in FCA-injected mice, whereas immobility was significantly $(P<0.01)$ increased in FCA-injected mice as compared to PBS-injected mice (Fig 2). Two days later immobility was still significantly $(P<0.01)$ increased in FCA-injected mice. Four days post immunization, no significant differences in recorded behaviour were observed.

\section{Pathological changes}

\section{Rabbits}

Though changes in clinical and behavioural parameters in rabbits were not seen, severe pathological changes did occur in some of these animals. The pathological changes observed in experiments I and II are summarized in Table 6.

Subcutaneous route RIBI and FA induced the most and more severe lesions than the other adjuvants. Lesions were often extensive (up to $100 \mathrm{~cm}^{2}$ ) and voluminous, combining proliferative and exudative features. Abscesslike lesions were observed only in RIBI-treated rabbits. Specol, TiterMax and Montanide resulted in lesions at secondary injection sites mainly (Fig 1B). Their presence and severity depended on the antigen added. Per adjuvant/antigen combination the overall severity score of s.c. lesions (Fig 3) was calculated by taking the sum of the mean primary and secondary lesion score, after applying a multiplication factor of 1.5 to the primary lesion score. This factor was applied to take into account possible reduction over time and longer duration of primary lesions.

Pathological changes of experiments III and IV are not summarized in Table 6 , since in these studies four injections, instead of one at a time, were given. When Specol was introduced to replace FA in routine polyclonal antibody production, combination with measles and mumps antigen resulted in unexpectedly severe lesions. In the next series Specol and FA were compared, and both antigens induced extensive /with measles antigen: more than 200 and more than $300 \mathrm{~cm}^{2}$ respectively and with mumps antigen almost 100 and more than $200 \mathrm{~cm}^{2}$ respectively) haemorrhagic lesions (experiment III) (Fig 1 A). Measles antigen without adjuvant $(n=5)$ did not induce gross lesions (data not shown), whereas mumps antigen $(n=1)$ induced an abscess-like lesion $160 \mathrm{~cm}^{2}$ totally). Injection of $4 \times 0.25 \mathrm{ml} F A$ without antigen $(n=1)$ induced extensive necrotizing granulomas. The same amount of Specol without antigen $(n=1)$ resulted in (extensive: $100 \mathrm{~cm}^{2}$ ) primarily exudative lesions, whereas after a single dose of $0.1 \mathrm{ml}(n=1)$ 

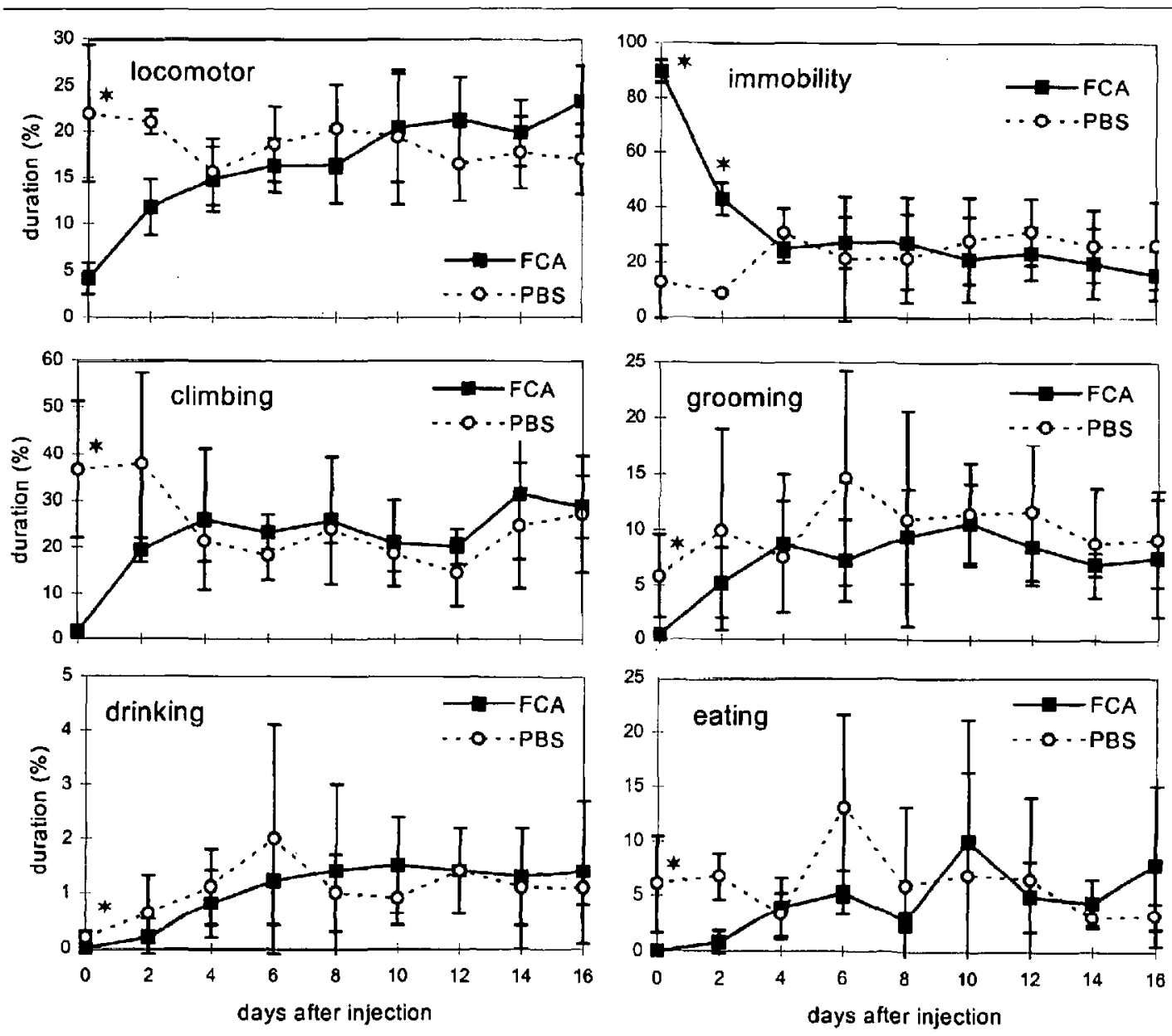

Fig 2 Results of LABORAS behaviour registration system (mice exp. III). Behavioural patterns of FCA and PBS injected $(0.2 \mathrm{ml}$ i.p.) mice are shown. Relative mean time ( $(S D)$ spent on behaviour per day during $4 \mathrm{~h}$ measuring period. ${ }^{*} \mathrm{P}<0.01$

minimal reaction was found (data not shown). In experiment IV, Specol and Montanide combined with HIV-pept/tt at relatively low doses $(4 \times 0.1 \mathrm{ml})$ were shown to induce exudative lesions, which at the most recently injected sites were more severe than those induced by FIA/HIV-pept/tt.

Intramuscular route Intramuscular lesions generally consisted of granulomas spreading parallel to muscle fibres, and showed less variation in size and character than s.c. lesions. Maximum cross diameter was $4 \mathrm{~cm}$ and in general length was 2 to 4 times the cross diameter. RIBI and FA induced the most and more severe lesions than the other adju- vants, which resulted in lesions mainly at secondary injection sites. The presence and severity of lesions depended on the antigen used. Necrosis in i.m. granulomas was commonest after RIBI injections. Necrosis of preexistent tissue was restricted to four RIBI cases and one exceptionally severe Specol (BSA) case. The overall severity score of i.m. lesions is given in Fig 3; the same calculation was applied as described for s.c. lesions.

\section{Mice}

Subcutaneous route Gross lesions found at primary injection sites varied slightly within groups, whereas lesions at secondary injec- 
Table 6 Pathological findings at injection sites of rabbits subcutaneously or intramuscularly injected with different adjuvant/antigen combinations

\begin{tabular}{|c|c|c|c|c|c|}
\hline \multirow[b]{2}{*}{ Adjuvant $^{\mathrm{a}}$} & \multirow[b]{2}{*}{ Antigen ${ }^{b}$} & \multicolumn{2}{|c|}{ Subcutaneous injection ${ }^{c}$} & \multicolumn{2}{|c|}{ Intramuscular injection } \\
\hline & & Primary & Secondary & Primary & Secondary \\
\hline \multirow[t]{5}{*}{ FA } & SPek15a & $4^{d}$ & 6 & 2 & 5 \\
\hline & Galacto & 6 & 4 & 2 & 0.5 \\
\hline & M. pneu. & 6 & 6 & 5 & 0 \\
\hline & Rubella & 4 & 5 & 6 & 3.5 \\
\hline & BSA & 5 & 6 & 6 & 5 \\
\hline \multirow[t]{5}{*}{ Specol } & SPek15a & 0 & 3 & 0 & 6 \\
\hline & Galacto & 0 & 0 & 0.5 & 0.5 \\
\hline & M. pneu. & 2 & 6 & 2 & 4.5 \\
\hline & Rubella & 0 & 0 & 0 & 0 \\
\hline & BSA & 4 & 6 & 4 & 6 \\
\hline \multirow[t]{3}{*}{ RIBI } & SPek15a & 7 & 4 & 5 & 3 \\
\hline & Galacto & 7 & 7 & 6 & 6 \\
\hline & M. pneu. & 5 & 8 & 5 & 6 \\
\hline \multirow[t]{3}{*}{ TiterMax } & SPek15a & 1 & 5 & 2 & 5 \\
\hline & Galacto & 1 & 2 & 0 & 2 \\
\hline & M. pneu. & 3 & 6 & 0 & 3 \\
\hline \multirow[t]{2}{*}{ Montanide } & Rubella & 0 & 0 & 0 & 1 \\
\hline & BSA & 2 & 4 & 2.5 & 4.5 \\
\hline
\end{tabular}

antigen controls (PBS + antigen): all primary injection sites negative; secondary injection sites: Galacto (i.m.), $M$. pneu. (i.m.) = severity score 1; Galacto $(s, c)=$ severity score 2

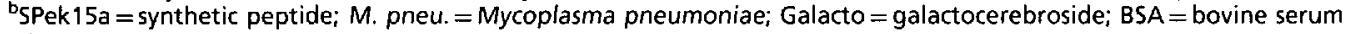
albumin

comparison between routes is not possible

'Mean of severity score at injection site of two rabbits; score as described in Table 3 in 'Animals, materials and methods' section

tion sites were almost identical within groups. At most primary injection sites of FCA, TiterMax and Montanide, white or yellow nodules $(2-10 \mathrm{~mm})$ were observed. Microscopically, granuloma formation, exudative diffuse inflammation and fibrosis were present at varying degrees (Figs 1C-D). Specol resulted only in marked lesions at the primary injection sites when combined with $M$. pneumoniae. After secondary injection of Specol/M. pneumoniae, and in some animals after secondary injection of TiterMax/SP215 or TiterMax without an antigen, circumscribed and/or hyperaemic nodules /up to $10 \mathrm{~mm}$ ) were found. At most secondary injection sites of other adjuvant/antigen combinations, grossly white, shiny tissue attached to muscles was found. Depending on the amount of this apparently innocuous reaction, it was visible externally as a white s.c. area after moistening the coat, and it caused bulging of the skin in the groin. Microscopically, diffuse exudative inflammation usually dominated (Figs 1E-F), the severity of which was mostly uniform within groups and did not always parallel the gross findings.

For the mean severity score of lesions per injection site, the sum of macroscopic and microscopic scores was applied. To obtain an overall severity score per injected adjuvant/ antigen combination, the sum of the mean primary lesion score (multiplied by 1.5) and the mean secondary lesion score was taken (as described for s.c. lesions in rabbits). The overall severity scores obtained in mice experiment II are given in Fig 4. The score for FA in this figure $( \pm 12)$ is representative for other antigens when combined with FA. The score of Specol when combined with $M$. pneumoniae was higher (10), and when combined with SP2 15 (experiment I) or MBP lower $( \pm 2)$ than the depicted overall severity score of \pm 5 for Specol/SP215. Injection of FA and RIBI in combination with antigen resulted in lesions comparable to those observed after injection of FA and RIBI without antigen. Specol and Montanide ISA50 without 


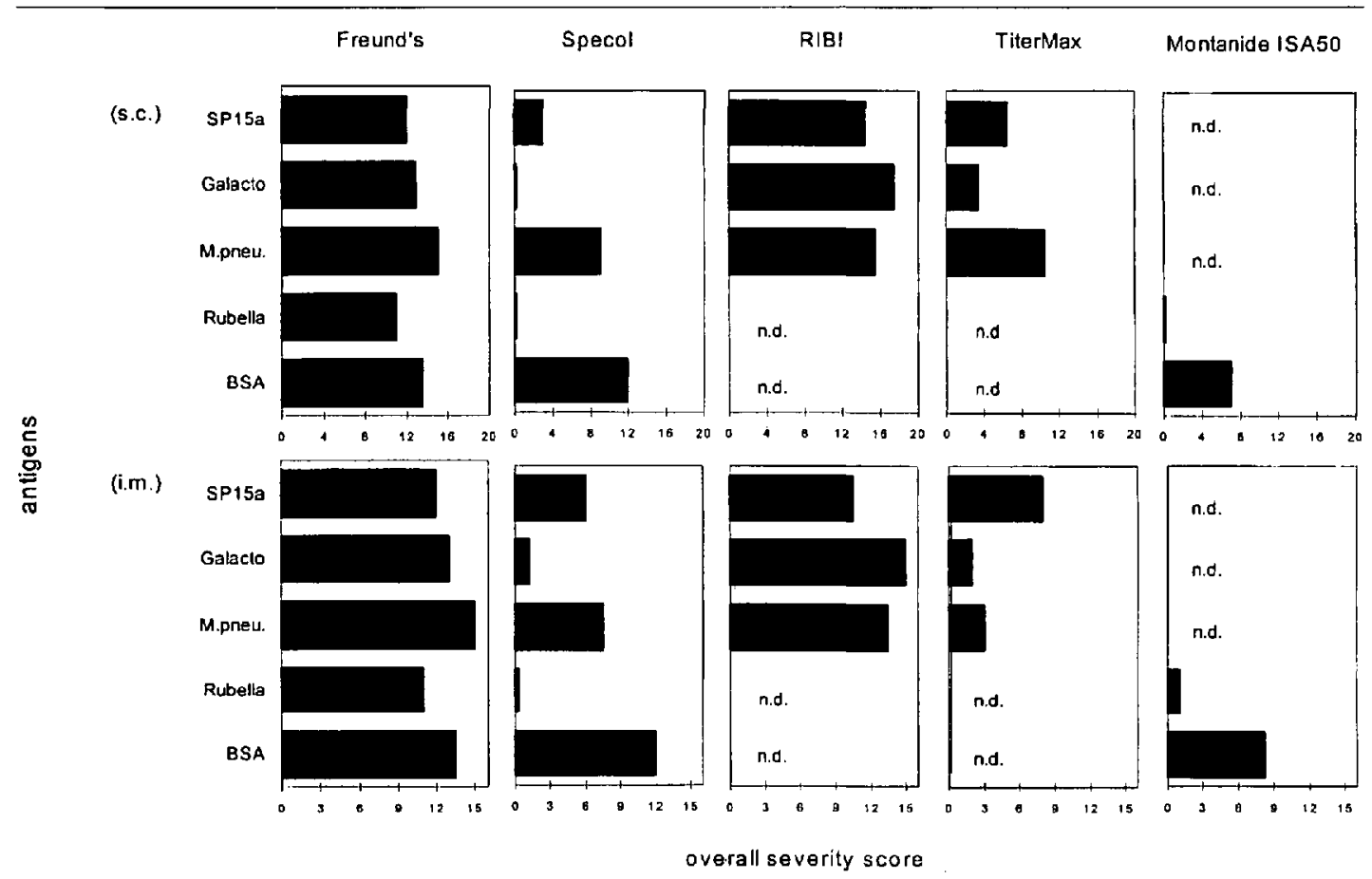

Fig 3 Overall pathological severity score of lesions after s.c. or i.m. injection of different adjuvant/antigen mixtures in rabbits $(n=2)$. For the overall severity score of lesions per adjuvant/antigen combination per route of injection, primary and secondary lesion scores were summed after applying a multiplication factor of 1.5 for the former score (see 'Pathological changes' in 'Results' section). Antigen controls (PBS + antigen) are described under Table 6

(s.c.)

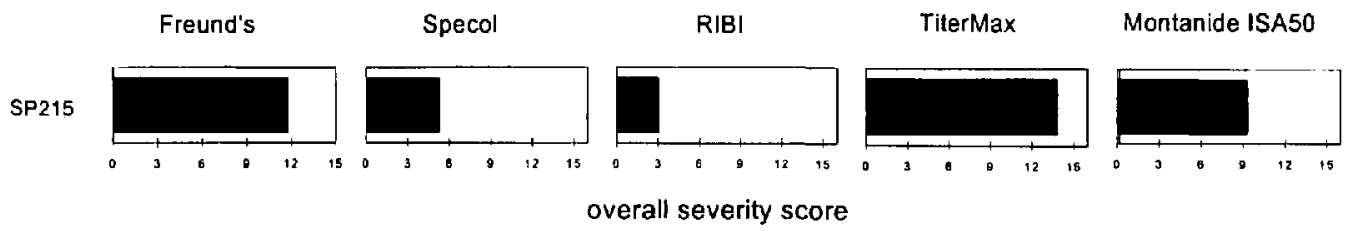

Fig 4 Overall pathological severity score of lesions after s.c. injection of adjuvant/SP215 mixtures in mice $(n=2-4)$. The overall severity score was calculated as described under Fig 3

antigen induced slightly milder lesions than those found after s.c. inoculation of the same adjuvants combined with antigen. TiterMax without antigen caused milder lesions than TiterMax with antigen. All antigen controls (antigen + PBS) were grossly negative. Microscopically, $M$. pneumoniae/PBS and SP215/PBS (mice experiment II) injection resulted in minimal or slight diffuse inflammation at secondary injection sites.

Intraperitoneal route Injection of FA and TiterMax resulted most consistently in severe pathological abnormalities. Severity of lesions caused by Specol depended on the antigen used. Pathological changes in i.p. treated mice are summarized in Table 7. Findings were homogeneous within groups. Adhesions, often extensive, were seen between small and large intestines, spleen and abdominal wall or in the hypogastrium, with shortening of the ligamentum latum. The pattern of adhesions was strikingly comparable within groups. Other signs of peritoneal irritation were milky effusions and dilatation of the small intestine. In less 
Table 7 Pathological findings in mice intraperitoneally injected with different adjuvant/antigen combinations

\begin{tabular}{|c|c|c|c|c|c|c|c|c|c|}
\hline \multirow[b]{2}{*}{ Adjuvant $^{a}$} & \multirow[b]{2}{*}{ Antigen $^{b}$} & \multicolumn{5}{|c|}{ Macroscopy } & \multirow{2}{*}{$\begin{array}{l}\text { Macroscopy } \\
\text { Overall } \\
\text { score }\end{array}$} & \multirow{2}{*}{$\begin{array}{l}\text { Microscopy } \\
\text { Severity } \\
\text { peritonitis }\end{array}$} & \multirow[b]{2}{*}{$\begin{array}{l}\text { Total } \\
\text { score }^{d}\end{array}$} \\
\hline & & Effusions & Adhesions & $\begin{array}{l}\text { Intestinal } \\
\text { dilatation }\end{array}$ & Plaques & $\begin{array}{l}\text { Omentum } \\
\text { retrahens }\end{array}$ & & & \\
\hline \multirow[t]{4}{*}{ FA } & MBP & 0 & 2 & 0 & 2 & 2 & 4 & 4.3 & 4 \\
\hline & M. pneu. & 0 & 0 & 0 & 2 & 1.5 & 2 & 4 & 2 \\
\hline & SPII $^{f}$ & 2 & 2 & 0 & 0 & 2 & 4 & 3 & 4 \\
\hline & - (PBS) & 1 & 0 & 0.5 & 0.5 & 1 & 3 & 3 & 3 \\
\hline \multirow[t]{5}{*}{ Specol } & SPI & 0 & 0 & 0 & 1 & 0 & 1 & 2 & 1 \\
\hline & MBP & 0.5 & 0 & 0 & 0.5 & 0 & 1 & 3 & 1 \\
\hline & M. pneu. & 0 & 0 & 0 & 1 & 1.5 & 2 & 3 & 2 \\
\hline & SPII & 0 & 2 & 2 & 0 & 2 & 4 & 4.5 & 4 \\
\hline & $-(\mathrm{PBS})$ & 0 & 1 & 2 & 0 & 1 & 4 & n.d. & 4 \\
\hline \multirow[t]{2}{*}{ RIBI } & SPII & 0 & 0 & 0 & 0.5 & 0 & 0 & 1.7 & 1 \\
\hline & $-(\mathrm{PBS})$ & 0 & 0 & 0 & 0 & 0 & 0 & 1.8 & 1 \\
\hline \multirow[t]{2}{*}{ TiterMax } & SPII & 2 & 1 & 1 & 0 & 2 & 4 & 2.8 & 4 \\
\hline & $-(\mathrm{PBS})$ & 2 & 1 & 0.5 & 1 & 1 & 4 & n.d. & 4 \\
\hline Montanide & SPII & 0 & 0 & 0 & 1 & 0.5 & 1 & 3.3 & 2 \\
\hline ISA50 & $-(\mathrm{PBS})$ & 0 & 0 & 0 & 0.5 & 0.5 & 1 & 1.7 & 1 \\
\hline FCA & $-(\mathrm{PBS})$ & 0 & 2 & 0 & 1 & 0 & 4 & n.d. & 4 \\
\hline
\end{tabular}

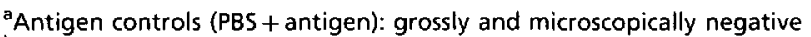

b $\mathrm{SPI}=$ synthetic peptide (mice experiment $\mathrm{I}$ ); $\mathrm{MBP}=$ myelin basic protein (autoantigen); $M$. pneu. = Mycoplasma pneumoniae; $\mathrm{SPII}=$ synthetic peptide (mice experiment II); $-=\mathrm{PBS}$, no antigen

'Mean macroscopic severity score $(n=4-5)$ : $0=$ absent; $1=$ moderate; 2 = marked

$0=$ negative-minimal; $1=$ slight; $2=$ moderate; $3=$ marked; $4=$ severe

e Mean microscopic severity score $(n=3-5): 0=$ negative; $1=$ minimal; $2=$ slight; $3=$ moderate; $4=$ marked; $5=$ severe

${ }^{f}$ Two out of five mice died after secondary immunization

severe cases, white, smooth, shiny thickening of the peritoneum covering liver, diaphragm and spleen (designated plaques) and/ or omentum retrahens were observed.

Microscopically, severity of peritonitis was assessed on the basis of mesothelial alteration, volume and character of peritoneal infiltrate, hyperaemia, and fibrosis. When no omentum could be recognized on account of severe omentum retrahens, the peritoneum covering the pancreas was analysed instead. Marked gross signs of active peritonitis were judged severe, regardless of microscopical score. In some groups, gross abnormalities were minimal or slight, though microscopy revealed peritonitis of unexpected severity. When this was the case, the total score was increased when compared to the macroscopic overall score. Mice in experiment III (LABORAS experiment) showed no pathological changes after i.p. injection with PBS, whereas FCA/PBS injection (i.p.) resulted in marked adhesions and plaques (Table 71 .

\section{Antibody responses}

Figure 5 shows the mean relative antibody titres (FA $=100 \%$ ) of the various adjuvant/ antigen combinations. Injection of FA/antigen resulted in high titred, specific antibody responses independent of the type of antigen. RIBI did not induce acceptable antibody responses, neither in rabbits nor in mice. TiterMax was not effective in inducing antibody responses in rabbits and mice, except when i.p. injected in mice. Specol and Montanide ISA50 induced antibody responses comparable to those induced by FA in rabbits and mice. Specol/autoantigen injection in mice, however, did not result in detectable antibody responses; Montanide ISA50 and also RIBI and TiterMax had not been injected in combination with autoantigen.

\section{Discussion}

In this paper, FA and alternative adjuvants were evaluated on their side effects, with the 


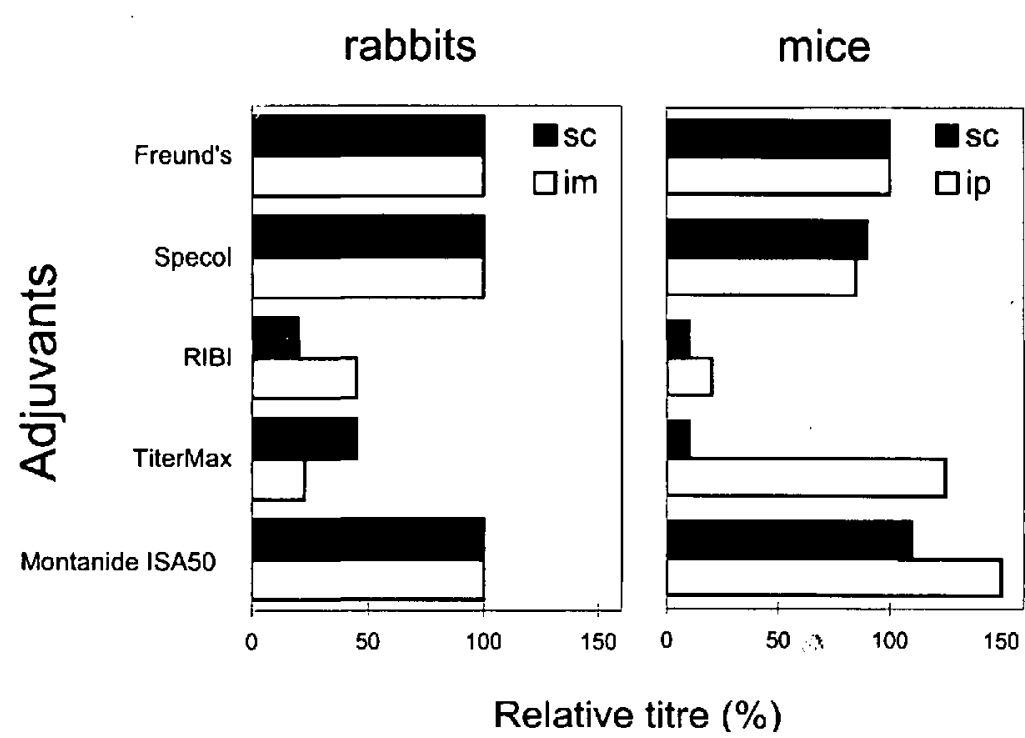

Fig 5 Relative antibody titre in serum of rabbits and mice after injection of different adjuvant/antigen combinations. Antibody titre in serum of FA/antigen injected animals was set on $100 \%$ aim of selecting an adjuvant which combines minor side effects with high antibody titres for a broad range of antigen types. Injection of FA resulted in moderate to severe pathological changes (Figs 3 and 4; Tables 6 and 7), confirming findings of Broderson et al. (1989), Toth et al. (1989) and Wiedemann et al. (1991). Literature data on side effects induced by alternative adjuvants compared with FA are scarce and relevant information is often only obtained from clinical observations. We consider necropsy essential to determine the side effects induced by adjuvant injection (e.g. i.m. lesions cannot properly be monitored in the living animal). In some cases, we observed extensive lesions at necropsy, though swellings or nodules were not palpable. Lesions in rabbits after RIBI injection were more severe than those induced by FA (Fig 3). Johnston et al. (1991), comparing FA, RIBI and Montanide ISA50, observed no differences in macroscopical abnormalities induced by these adjuvants. In contrast, Deeb et al. (1992) observed mild lesions after RIBI injection in rabbits. In our studies in mice, RIBI induced minimal pathological changes (Fig 4 and Table 7). Lipman et al. (1992) observed less extensive lesions (adhesions and white plaques on organs) after i.p. injection of RIBI in mice compared with FA-induced lesions. After injection of TiterMax in rabbits (Fig 3) we observed slight lesions, whereas injection of TiterMax in mice resulted in severe lesions (Fig 4 and Table 7). Bennett et al. (1992) studied histopathological changes after i.m. injection of $2 \times 40 \mu \mathrm{l}$ TiterMax/TNP.HEA in mice and found mild lesions. In our study, Montanide ISA50 injections resulted generally in less severe lesions when compared to FA injections, both in rabbits and mice (Figs 3 and 4; Tables 6 and 7). Johnston et al. (1991) injected rabbits with Montanide ISA50 and observed similar lesions as those induced by FCA. These differences in pathological changes between this study by Johnston et al. (1991) and our study may be explained by the fact that different antigens were used.

Pathological investigation was performed at the end of each experiment. Consequently, continuous monitoring of the lesions by macroscopy and microscopy was not possible. Generally, the monitoring time point was 2 weeks in rabbits and 5 days in mice after secondary injection, so that lesions at primary injection sites were present at least 6 weeks. To discriminate between primary and secondary injections, they were given at different sites. Primary injection sites were negative more often that secondary ones. Apart from healing of the inflammation, immunopathological phenomena (as a result of repeated introduction of antigen/ are likely to play a role in secondary lesions. As there 
was only one point of monitoring, rapidly resolving inflammatory reactions may have been missed, especially in rabbits (lesions at least 2 weeks old). A certain lesion, found at the primary injection site (at least 6 weeks old), is presumed to have impaired the animal more than an identical lesion found at the secondary injection site. To compensate for this, scores of primary injection sites were augmented by a factor 1.5 before summing up primary and secondary scores, and reaching an overall severity score per adjuvant/antigen combination (Figs 3 and 4).

Microscopy was performed because it adds useful observations to gross data. Lesions at s.c. injection sites in mice showed some remarkable differences in macroscopic and microscopic findings. At the s.c. primary injection site in mice, grossly observed impressive nodules occasionally appeared to consist merely of one or several large 'oil spaces' surrounded by slight or moderate (fibro)granulomatous proliferation. On the other hand, macroscopically identically scored lesions were found to display marked diffuse and granulomatous inflammation and marked fibrosis around variably sized 'oil spaces'. Microscopical examination of s.c. secondary injection sites in mice revealed grossly unexpected severe inflammation in some groups. It is not known why these microscopically marked exudative lesions are hardly seen macroscopically. Haemorrhage was absent in lesions in mice but was present in lesions in rabbits that showed marked hyperaemia in exudative lesions despite exsanguination. When macroscopical examination of s.c. and i.m. injection sites does not reveal pathological changes, additional information from microscopy depends on successful sampling. The i.p. route can always be monitored microscopically and mild or resolving peritonitis (missed grossly) can be assessed in a more sensitive way. As in rabbits macroscopical severity correlated well with microscopical severity, microscopy was only used to verify gross findings. The same holds true for the i.p. route in mice. In s.c. treated mice, macro- and microscopical findings were taken together, because these findings did not correlate well. Apart from the adjuvant, other factors may determine the severity of lesions, e.g. antigen type and injection route. The lesions seen after injection of $M$. pneumoniae combined with all tested adjuvants were relatively severe in rabbits. Hardly any lesion was observed when it was injected without an adjuvant. In combination with measles or mumps antigen, Specol induced extensive lesions (less extensive than FA) in rabbits, whereas in combination with other antigens (e.g. synthetic peptide, glycolipid) it induced minimal to mild lesions. This may be explained by either the volume injected $(4 \times 0.25 \mathrm{ml})$ or the particulate character of the antigens.

Severity of lesions cannot simply be compared between injection routes. In our opinion the i.p. injection route should be rejected, owing to the extensive surface of the peritoneum, its high susceptibility to physicochemical damage and its intimate contact with various vital organs. Especially the acute phase of peritonitis is believed to be painful. In abdominal tissue of mice, we observed acute exudative inflammation 2 to $96 \mathrm{~h}$ after i.p. FCA/TNP-KLH injection $(0.2 \mathrm{ml}$ ) (data not shown). Jansen van 't Land and Hendriksen (1995) showed decreased locomotor activity on the first day after i.p. injection of $0.2 \mathrm{ml} \mathrm{FCA}$. In our LABORAS experiment, locomotion, climbing, grooming, eating and drinking were significantly reduced after i.p. injection of FCA/PBS /Fig 2). In addition, secondary injection via the i.p. route caused some deaths, probably on account of systemic reactions. In rabbits the pathological findings do not clearly point at a preferential route. The i.m. route is more prone to injection error (i.e. wrong localization of adjuvant/antigen mixture) and more painful than the s.c. one. Moreover, i.m. lesions are more difficult to monitor clinically. The s.c. loose areolar tissue will permit spread of inoculum and inflammation more easily than the rigid muscle compartment, indeed resulting in larger s.c. lesions. Intramuscular lesions probably exert more pressure on the surrounding tissue. Hence, considering the s.c. and i.m. route, pain experienced by the animal is not only a function of lesion size and character. Although s.c. lesions were sometimes very 
extensive, we find reason to prefer the s.c. route to the i.m. route.

An effective adjuvant (Fig 5) that induces minimal pain in the animals is preferred for immunization. In rabbits, no clinical or behavioural changes indicating pain and distress were observed. Mice revealed signs of acute pain and distress (e.g. weight loss, decrease in activity and piloerection) during the first few days after injection. Although signs of prolonged severe pain and distress were absent, marked to severe pathological changes did occur after injection of several of the adjuvant/antigen mixtures (Figs 3 and 4; Tables 6 and 7). It is not possible to give an estimation of pain associated with the observed pathological changes, because we did not observe indications of prolonged pain and distress. In mice, only acute distress was found. The available methods may be inadequate to monitor prolonged pain and distress, especially in the rabbit, because this species does not readily exhibit pain signs (Wallace $e t$ al. 1990, Griffiths 1991). Mice showed signs of acute pain; if they experienced prolonged pain this was not revealed by clinical and behavioural changes, indicating that they are able to cope with the induced pathological changes or that these changes are not or less painful than is presumed. Devices like LABORAS (Van de Weerd 1996, Bulthuis et al. 1997) enable the recording of subtle changes in the behavioural pattern of mice, offering the possibility to monitor pain and distress.

We injected the animals in accordance with the Dutch guidelines for the immunization of laboratory animals, e.g. FCA in primary and FIA in secondary injection. This may be the reason why minimal signs of pain and distress were found. Johnston et al. (1991) did not observe indications for pain in rabbits, although marked pathological changes were found. Amyx (1987) suggested that most undesirable effects of FCA can be eliminated by careful control of injection quantity and site selection. The pathological changes induced by FCA are thought to be (potentially) very painful, in analogy to humans. Therefore, reports on accidental and intentional human injections can provide information on pain induced by FCA. Chapel and August (1976) reported severe pain after accidental injections in humans. However, all persons who suffered severe pain were positive to the tuberculin test prior to the accidental injection, indicating that the reaction was a result of repeated exposure to mycobacteria (Stills \& Bailey 1991). Wanstrup and Christensen (1965) injected mice weekly with FCA and observed decreased activity, dullness of fur and loss of hair.

In conclusion, we did not observe clinical and behavioural changes indicative for severe prolonged pain and distress (only acute distress in mice was observed), although some adjuvants were associated with severe pathological changes in this study. Pathological changes are considered an essential parameter to study side effects of adjuvants. The s.c. route is superior to the i.m. route (rabbits) or i.p. route (mice). Montanide ISA50 and Specol appear to induce acceptable antibody responses and less pathological changes than FA, and are, therefore, effective alternatives to FA in many situations.

Acknowledgments The authors thank C. Moolenbeek, D. Kegler, P. van Schaaik, H. Strootman, R. van Kinderen, J. Visser, L. van de Berg, G. Germans and S. Luypen for technical assistance; $S$. de Waal and G. van Leuveren for histotechnical work; $H$. van Herck, F. Schlingmann and J. Tolboom for help with LABORAS data and Professor J. E. van Dijk for helpful discussion.

\section{References}

Amyx HL (1987) Control of animal pain and distress in antibody production and infectious disease studies. Journal of the American Veterinary Medical Association 191, 1287-9

Bennett B, Check IJ, Olsen MR, Hunter RL (1992) A comparison of commercially available adjuvants for use in research. Journal of Immunological Methods 153, 31-40

Boersma WIA, Deen C, Gerritse K, Zegers ND, Haaijman IJ, Claassen E (1989) Anti-peptide antibodies as a subclass specific reagent: epitope mapping of human IgG2. Protides of the Biological Fluids 36, 161-5

Boersma WJA, Bogaerts WJC, Bianchi ATJ, Claassen E (1992) Adjuvant properties of stable water-in-oil emulsions: evaluation of the experience with Specol. In: 44th Forum in Immunology. Research in Immunology 143, 503-12

Bokhout BA, Van Gaalen C, Van der Heijden PhJ (1981) A selected water-in-oil emulsion: composi- 
tion and usefulness as an immunological adjuvant. Veterinary Immunology and Immunopathology 2, 491-500

Broderson JR (1989) A retrospective review of lesions associated with the use of Freund's adjuvant. Laboratory Animal Science 39, 400-5

Broom DM, Johnson KG (1993) Stress and Animal Welfare. London: Chapman \& Hall Animal Behaviour Series

Bulthuis JA, Bergman AF, Nijessen S, et al. (1997) Automated behaviour classification: the LABORAS project. In: Harmonization of Laboratory Animal Husbandry (O'Donoghue PN, ed). London: Royal Society of Medicine Press, pp 17-18

Canadian Council on Animal Care (1991) CCAC Guidelines on Acceptable Immunological Procedures. Ottawa, Ontario, Canada, $2 \mathrm{pp}$

Chapel HM, August PJ (1976) Report on nine cases of accidental injury to man with Freund's complete adjuvants. Clinical and Experimental Immunology 24, 538-41

Claassen E, Boersma WJA (1992) Characteristics and practical use of new-generation adjuvants as an acceptable alternative to Freund's complete adjuvant. In: 44th Forum in Immunology. Research in Immunology 143, 475-7

Cox JC, Coulter AR (1997) Adjuvants-a classification and review of their modes of action. Vaccine 15, 248-56

Deeb BJ, DiGiacomo RF, Kunz LL, Stewart JL (1992) Comparison of Freund's and RIBI adjuvants for inducing antibodies to the synthetic antigen (TG)AL in rabbits. Joumal of Immunological Methods 152, 105-13

Ganne V, Eloit M, Laval A, Adam M, Trouve G (1994) Enhancement of the efficacy of a replicationdefective adenovirus-vectored vaccine by the addition of oil adjuvants. Vaccine 12, 1190-6

Gerritse K, Slierendregt B, Deen C, Fasbender MI, Boersma WJA, Claassen E (1993) In situ detection of self reactive epitope specific antibody forming cells in the central nervous system of EAE rhesus monkey. EOS-Journal of Immunology and Immunopharmacology 3, 63-5

Griffiths PHM (1991) Clinical assessment of pain, distress and discomfort. In: Animals in Biomedical Research; Replacement, Reduction and Refinement: Present Possibilities and Future Prospects (Hendriksen CFM, Koëter HBWM, eds). Amsterdam: Elsevier Science Publishers, pp 235-46

Hunter RL, Olsen MR, Bennett B (1995) Copolymer adjuvants and TiterMax. In: The Theory and Practical Application of Adiuvants (Stewart-Tull DES, ed). Chichester: John Wiley \& Sons, pp 51-94

Irwin S (1968) Comprehensive observational assessment: Ia. A systematic, quantitative procedure for assessing the behavioural and physiological state of the mouse. Psychopharmacology Series (Berlin) 13, 222-57
Jansen van 't Land C, Hendriksen CFM (1995) Change in locomotor activity pattern in mice: a model for recognition of distress? Laboratory Animals 29, 286-93

Johnston BA, Eisen H, Fry D (1991) An evaluation of several adjuvant emulsion regimens for the production of polyclonal antisera in rabbits. Laboratory Animal Science 41, 15-21

Leenaars PPAM, Hendriksen, CFM, Angulo AF, Koedam MA, Claassen E (1994) Evaluation of several adjuvants as alternatives to the use of Freund's adjuvant in rabbits. Veterinary Immunology and Immunopathology 40, 225-41

Leenaars PPAM, Hendriksen CFM, Koedam MA, Claassen I, Claassen E (1995) Comparison of adjuvants for immune potentiating properties and side effects in mice. Veterinary Immunology and Immunopathology 48, 123-38

Lipman NS, Trudel LJ, Murphy JC, Sahali Y (1992) Comparison of immune response potentiation and in vivo inflammatory effects of Freund's and RIBI adjuvants in mice. Laboratory Animal Science 42, 193-7

Morton DB, Griffiths PHM (1985) Guidelines on the recognition of pain, distress and discomfort in experimental animals and an hypothesis for assessment. The Veterinary Record 116, 431-6

Parkman PD, Meyer HM (1966) Attenuated rubella virus. I. Development and laboratory characterization. New England Journal of Medicine 275, 569-74

Rudbach JA, Johnson DA, Ulrich JT (1995) RIBI adjuvants: chemistry, biology and utility in vaccines for human and veterinary medicine. In: The Theory and Practical Application of Adjuvants (Stewart-Tull DES, ed). Chichester: John Wiley \& Sons, pp 287-313

Stills HF, Bailey MQ (1991) The use of Freund's complete adjuvant. Lab AnimaI 20, 25-30

Su CI, Dallo SF, Baseman JB (1990) Molecular distinctions among clinical isolates of Mycoplasmo pneumoniae. Journal of Clinical Microbiology 29, $1538-40$

Toth LA, Dunlap AW, Olson GA, Hessler JR (1989) An evaluation of distress following intraperitoneal immunization with Freund's adjuvant in mice. Laboratory Animal Science 39, 122-6

Van Binnendijk RS, Van der Heijden RWJ, Van Amerongen G, UytdeHaag FGCM, Osterhaus ADME (1994) Viral replication and development of specific immunity in macaques after infection with different measles virus strains. Toumal of Infectious Diseases 170, 443-8

Van de Weerd HA (1996) Environmental enrichment for laboratory mice: preferences and consequences (PhD Thesis). The Netherlands: Utrecht University Van Noort JM, Van Sechel A, Boon J, Boersma WIA, Polman CH, Lucas CJ (1993) Minor myelin proteins can be major targets for peripheral blood $\mathrm{T}$ cells 
from both multiple sclerosis patients and healthy subjects. Journal of Neuroimmunology 46, 67-72

Veterinary Public Health Inspectorate (1993) Code of Practice for Immunization of Laboratory Animals. Working Group on Immunization Procedures, Rijswijk, Veterinary Public Health Inspectorate (VH1), $34 \mathrm{pp}$

Vogel FR, Powell MF (1995) A compendium of vaccine adjuvants and excipients. In: Vaccine Design, the Subunit and Adjuvant Approach (Powell MF, Newman MJ, eds). Pharmaceutical Biotechnology Series 6. New York: Plenum Publishing Corp., pp 141-228

Wallace J, Sanford J, Smith MW, Spencer KV (1990) The assessment and control of the severity of scientific procedures on laboratory animals. Laboratory Animals 24, 97-130
Wanstrup J, Christensen HE (1965) Granulomatous lesions in mice produced by Freund's adjuvant. Acta Pathologica Microbiologica et Immunologica Scandinavica 63, 340-54

Wiedemann F, Link R, Pumpe K, et al. (1991) Histopathological studies on the local reactions induced by complete Freund's adjuvant (CFA), bacterial lipopolysaccharide (LPS), and synthetic lipopeptide $\left(\mathrm{P}_{3} \mathrm{C}\right)$ conjugates. Joumal of Pathology 164, 265-71

Zegers ND, Van Holten C, Claassen E, Boersma WIA (1993) Peptide-induced memory (IgG) response, cross-reactive with native proteins, requires covalent linkage of a specific B cell epitope with a T cell epitope. European Journal of Immunology 23, $630-4$ 